Лапин А.A.

\title{
О ПРОБЛЕМАХ ВИКТИМОЛОГИЧЕСКОЙ ПРОФИЛАКТИКИ ПРЕСТУПЛЕНИЙ И НАПРАВЛЕНИЯХ ПО ЕЕ СОВЕРШЕНСТВОВАНИЮ
}

Аннотация: События последних лет свидетельствуют, что преступность, по-прежнему, находится на уровне, угрожающем безопасности населения. В статье на основе анализа сделан вывод о том, что преступность по-прежнему представляет серьезную угрозу для безопасности граждан. Отмечается, что с системе профилактики правонарушений особое место занимает работа с жертвами преступлений - виктимологическая профрилактика. Указывается, что антикриминогенный потенциал виктимологической профилактики используется еще не в полной мере, чему способствует ряд фракторов. Для подготовки статьи автором были использованы следующие методологические основы: совокупность общенаучных и специальных методов познания социально-правовой действительности. Методологический базис исследования представлен диалектическим методом с присущими ему требованиями объективности, всесторонности, историзма, конкретности истины. Из числа общенаучных методов исследования использовались методы анализа, синтеза, сравнения, измерения. В качестве частно научного метода применялся метод сравнительно-правовой. Проведенный анализ практики деятельности правоохранительных органов и теоретических работ ученых позволяет утверждать, вопрос об использовании возможностей виктимологической профрилактики, по-прежнему, актуален. Его разрешение является насущной необходимостью, ибо отсутствие виктимологической профилактики или слабое использование ее возможностей существенно ослабляет эффрективность деятельности по предупреждению преступлений в целом.

Ключевые слова: Преступность, правоохранительные органы, виктимологическая профилактика, жертвы преступлений, потерпевший, уголовное право, международный опыт, общественная безопасность, правовое регулирование, методология систематизации.

Review: The recent events demonstrate that criminality is still on the level, threatening the safety of the population. On the base of the analysis, the author concludes that criminality is still dangerous for the safety of the population. The author notes that within the crime prevention system, the work with the victims of crimes (victimological prevention) plays an important role. It is noted that anti-criminogenic potential of victimological prevention is used insufficiently due to several reasons. The research is based on the set of general scientific and special methods of cognition. The methodological basis of the study comprises the dialectical method with its requirements of objectivity, comprehensiveness, historicism and clarity of truth. Among general scientific 
methods of research the author applies the methods of analysis, synthesis, comparison, measurement. The comparative-legal method is used as a special research method. The analysis of the work of law machinery and the theoretical scientific works demonstrates that the issue of the use of the potential of victimological prevention is still the problem of today. Its solution is an urgent necessity, since the absence of victimological prevention of its insufficient use reduces the efficiency of prevention of crimes in general.

Keywords: Public safety, international experience, criminal law, victim, victims of crimes, victimological prevention, law machinery, crime, legal regulation, methodology of systematization.

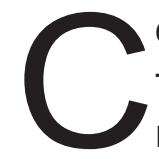

обытия последних лет свидетельствуют, что преступность, попрежнему, находится на уровне, угрожающем безопасности населения. Официальная статистика показывает, что государство пока не в состоянии обеспечить достаточного уровня безопасности граждан от преступлений. Последние пять лет характеризуются снижением числа зарегистрированных преступлений: 2009 г. - 2994820 (- 6,7 \%), 2010 г. - 2628799 (- 12, 2 \%), 2011 г. - 2404807 (-8,5 \%), 2012 г. - 2302168 (-4,3 \%), 2013 г. - 2206249 (-4,2 \%), 2014 г. - 2190578 (-0,7 \%) [1]. Но даже при указанном снижении числа зарегистрированных преступлений зафиксированы тревожные сведения о числе погибших людей и причинении тяжкого вреда здоровью. В частности, в результате различных преступлений в 2010 г. погибло 30275 людей, в 2011 г. - 30476 , 2012 г. - 31736, 2013 г. - 31111, 2014 г. - 32611[1]. В подобной ситуации граждане на протяжении ряда лет, по-прежнему опасаются за свою жизнь, здоровье и собственность.

Обеспечение безопасности личности в Российской Федерации в современных условиях обусловливает необходимость активной деятельности по профилактике правонарушений.
В системе профилактики правонарушений особое место занимает работа с жертвами преступлений - виктимологическая профилактика.

В научной и учебной литературе существует ряд, по своей сути сходных, определений виктимологической профилактики.

А.И. Алексеев определил виктимологическую профилактику как специфическую деятельность социальных институтов, направленную на выявление, устранение или нейтрализацию факторов, обстоятельств, ситуаций, формирующих виктимное поведение и обусловливающих совершение преступлений; выявление групп риска и конкретных лиц с повышенной степенью виктимности и воздействие на них в целях восстановления или активизации защитных свойств, а также разработка либо совершенствование уже имеющихся специальных средств защиты граждан от преступлений и последующей виктимизации[2, С. 155-156].

По мнению В.И. Задорожного, «виктимологическая профилактика - это специфическая деятельность субъектов предупреждения преступлений по реализации общих и индивидуальных мер, направленных на снижение у насе- 
ления и отдельных граждан риска стать жертвами преступных посягательств и включающих: 1) выявление, устранение или нейтрализацию факторов, обстоятельств, ситуаций, формирующих виктимное поведение отдельных лиц и обусловливающих совершение преступлений; 2) выявление «групп риска» и конкретных лиц с повышенной виктимностью с целью восстановления или активизации их защитных свойств; 3) разработка и совершенствование охраннозащитных возможностей потенциальных жертв преступлений» [3, С 36-37].

К сожалению, пока в нашей стране виктимологическая профилактика пока еще не получила достаточного распространения. А.И. Алексеев подчеркнул, что виктимологическая профилактика - одно из направлений предупреждения преступности, далеко не в полной мере реализованное в нашем обществе [2, C. 155].

Об этом же писали и другие ученые. В частности, Г.Г. Смирнов в своей монографии «Проблемы развития и реализации криминологического учения о предупреждении преступности» также указал, что виктимологическое предупреждение обладает огромным антикриминогенным потенциалом, который реализуется еще не в полной мере [4. С. 133].

В литературе совершенно обоснованно высказывается мнение, что российское общество слабо защищает жертв преступлений, государственными органами данная деятельность практически не осуществляется [5, С.83]. Более жесткую позицию по этому поводу высказал С.А. Невский: «... в настоящее время потерпевшие от преступлений в России являются дважды потерпевшими: вопервых, непосредственно от преступле- ния, во-вторых, от отношения государственных органов и их должностных лиц, рассматривающих во многих случаях потерпевших как досадную «обузу» для работы правоохранительных органов»[6]. Позиция, на наш взгляд, категоричная, но имеющая право на существование.

Один из основателей отечественной виктимологии В.И. Полубинский очень верно отметил, что известная ограниченность возможностей виктимологической профрилактики и ее пока что недостаточная эффективность помимо других причин объясняется также и тем, что интерес как ученых, так и практиков в области борьбы с преступностью концентрируется главным образом на правонарушителе, реже - на преступном акте. Жертве же преступления, по его убеждению, теоретики права и практические работники правоохранительных органов до сих пор должного внимания не уделяют[7. С. 6].

Очень актуальным является утверждение В.И. Полубинского, что только комплексное и всестороннее изучение личности преступника и его жертвы, их взаимоотношений, объективные роли, которую каждый из них сыграл в противоправном акте, позволяет сделать точный и правильный вывод об ответственности виновного в правонарушении, а также установить обстоятельства, способствующие его совершению. С другой стороны, подчеркивает В.И. Полубинский, знание личностных особенностей жертвы, ее роли в зарождении и развитии преступления, анализ и характеристика отношений между правонарушителем и потерпевшим с позиций свойств жертвы и ее поведении значительно расширяют возможности профилактики и борьбы с преступностью[8. С. 5]. 
Ученые постоянно призывают к пересмотру взглядов на использование потенциала виктимологической профилактики.

А.И. Алексеев обоснованно призывал, что необходимо изменить существующий взгляд на сложившуюся практику борьбы с преступностью, в частности, ее предупреждения, сделать виктимологическую профилактику более весомым и эфффективным направлением в предупреждении преступности[2, С. 159]. При этом, по его мнению, в перспективе целесообразно создать государственную службу по поддержке жертв преступлений, оказанию потерпевшим социальнопсихологической, правовой и иной помощи. Учитывая роль органов внутренних дел, он считал, что реальной, по крайней мере, применительно к крупным горрайорганам внутренних дел, является постановка вопроса о специализации сотрудников по линии работы с потерпевшими и другими жертвами[2, с. 169].

Сходную позицию высказывал Г.Г. Смирнов, который говорил о важности научно-методического обеспечения виктимологического предупреждения. Оно, по его мнению, должно способствовать разработке и принятию междисциплинарного федерального закона «О защите жертв преступлений», оптимальному решению ряда организационных вопросов в данной сфрере, в таких, например, как налаживание полного учета жертв преступлений, создание специализированной государственной службы и общественных фондов по поддержке жертв преступлений, улучшение виктимологического просвещения населения [4, C. 134].

Позиция о необходимости принятия правового акта, регламентирующего во- просы зашиты жертв преступлений высказывалась и иными учеными.

Е.Н. Клещина, констатируя отсутствие на государственном уровне концепции защиты потерпевших от преступлений, подчеркивает, что это не позволяет в полной мере знать количество потерпевших, характер причиненного им вреда, ситуации, связанные с возмещением вреда, защитой их прав и законных интересов в ходе уголовного судопроизводства. По ее мнению, необходимо принятие Указа Президента Российской Федерации «Концепция защиты потерпевших от преступлений в Российской Федерации», который должен определять виктимологическую политику в стране. В данной Концепции необходимо указать, что информирование и помощь потерпевшим от преступлений является приоритетной задачей правоохранительных органов и общественных организаций. Е.Н. Клещина считает, что с целью исполнения положений «Концепции защиты потерпевших от преступлений в Российской Федерации» в каждом ведомстве необходимо создать управления по контролю за исполнением указанного документа. В каждом территориальном органе внутренних дел должны работать специальные сотрудники - инспектора по оказанию помощи жертвам [9, С. 156-158].

М.А. Мусаев в своей книге «Защита жертв преступлений» уделил внимание печальной участи проекта Положения о Государственном фонде помощи жертвам насильственных преступлений, разработанному еще в 1997 г. учеными НИИ проблем укрепления законности и правопорядка при Генеральной прокуратуре Российской Федерации. Как он отметил, это был детально отработанный и юри- 
дически состоятельный документ, включавший разделы общих положений, о порядке деятельности фонда и основаниях получения помощи фонда, источниках его фринансирования. Судьба этого документа была печальна. В ведомствах, куда проект Положения был направлен руководством НИИ, он был положен «под сукно», где и истлел за десять с лишним лет. По мнению М.А. Мусаева, слабое использование отечественной судебной практикой положений международных пактов о защите жертв преступлений актуализирует идею подготовки фундаментального межотраслевого правового акта «О защите жертв преступных посягательств» [10, С. 104-105].

Проведенный анализ практики деятельности правоохранительных органов и теоретических работ ученых позволяет утверждать, вопрос об использовании возможностей виктимологической профрилактики, по-прежнему, актуален. Его разрешение является насущной необходимостью, ибо отсутствие виктимологической профилактики или слабое использование ее возможностей существенно ослабляет эффрективность деятельности по предупреждению преступлений в целом.

\section{Библиография:}

1. Преступность и правонарушения (2010 - 2014). Статистический сборник. М., 2015.

2. Алексеев А.И. Криминология. Курс лекций. Издание четвертое, исправленное и дополненное. M., 2004.

3. Задорожный В.И. Виктимологическая безопасность и ее обеспечение мерами виктимологической профилактики. Тамбов, 2005.

4. Смирнов Г.Г. Проблемы развития и реализации криминологического учения о предупреждении преступности. Екатеринбург, 2007.

5. Долженкова Г.Д. Некоторые проблемы социальной защиты жертв преступлений в Российской Федерации // Преступность и общество. М., 2005.

6. Невский С.А. Обеспечение безопасности личности в России в условиях социально-экономической нестабильности (проблемы, поиски решений) // Общество и право. 2009. № 5.

7. Полубинский В.И. Фундаментальные и прикладные начала криминальной виктимологии. М., 2010.

8. Полубинский В.И. Криминальная виктимология. М., 2008.

9. Клещина Е.Н. Криминологическое учение о жертве преступления и его практическая реализация. М., 2010.

10. Мусаев М. А. Защита жертв преступлений. М., 2012.

\section{References (transliterated):}

1. Prestupnost' i pravonarusheniya (2010 - 2014). Statisticheskii sbornik. M., 2015.

2. Alekseev A.I. Kriminologiya. Kurs lektsii. Izdanie chetvertoe, ispravlennoe i dopolnennoe. M., 2004.

3. Zadorozhnyi V.I. Viktimologicheskaya bezopasnost' i ee obespechenie merami viktimologicheskoi profilaktiki. Tambov, 2005.

4. Smirnov G.G. Problemy razvitiya i realizatsii kriminologicheskogo ucheniya o preduprezhdenii prestupnosti. Ekaterinburg, 2007.

5. Dolzhenkova G.D. Nekotorye problemy sotsial'noi zashchity zhertv prestuplenii v Rossiiskoi Federatsii // Prestupnost' i obshchestvo. M., 2005. 
6. Nevskii S.A. Obespechenie bezopasnosti lichnosti v Rossii v usloviyakh sotsial'no-ekonomicheskoi nestabil'nosti (problemy, poiski reshenii) // Obshchestvo i pravo. 2009. № 5.

7. Polubinskii V.I. Fundamental'nye i prikladnye nachala kriminal'noi viktimologii. M., 2010.

8. Polubinskii V.I. Kriminal'naya viktimologiya. M., 2008.

9. Kleshchina E.N. Kriminologicheskoe uchenie o zhertve prestupleniya i ego prakticheskaya realizatsiya. M., 2010.

10. Musaev M. A. Zashchita zhertv prestuplenii. M., 2012. 